\title{
Local Discourse of Muslim Women's Leadership and Citizenship: A Case Study of Female Posyandu in Tasikmalaya
}

\author{
Kusmana, Ph.D. \\ Lecturer of Faculty of Ushuluddin, UIN SyarifHidayatullah Jakarta
}

\begin{abstract}
Womens' position in the society has been neglected, considered as a second-class citizen due to the social forces that include the perceived kodratperempuan (constructed woman's nature) norm that restrict their social engagement. The previous studies indicatethat the normis seen as the main restricting factor. Therefore, women's social engagement is restrictive and stagnant. The present research contends this finding and argues that it is not a fixed value as perceived by feminists, but rather a flexible one because it is nurtured. It maychange from time to time and is different from one place to another. Different from the feminist's stand, this study perceives that women in dealing with the restricting function of the constructed kodratperempuan often find ways to extend their role and status. It proves that, therefore, her social engagement is dynamic.Using a descriptive analytic method and Anthony Giddens's perspective of an agency, this study answers the research question "how Muslim women cadres of Posyandu in the Regency and City of Tasikmalaya tackle the barriers they faced in enabling and enacting leadership?" The researcher identifies internal and external factors that influence their perception of kodratand relates their attitudes to their social engagement as leaders of the cadres of Posyandu in the villages of this Regency and City. The data which were collected through observation, interview, and library review is interpreted in the nuance of cultural citizenship. The study finds that through these restricted rooms and opportunities perpetuated by the norm of the constructed kodrat, some female cadres initially take advantages of their supporting internal and external factors in tackling barriers in their leadership at Posyandu's activities. Later on, they manage to practice citizenship as men do, and to certain extents, they are even more creative and havemore a significant role rather than some men can do.
\end{abstract}

Key Terms: Constructed KodratPerempuan, leadership, and cultural citizenship

\section{INTRODUCTION}

This article discusses citizenship expressions of Posyandu female cadres' leadership, seen from the perception of kodratperempuan. This sort of case study has rarely been done. The significance of this study is marked by the fact that politics and power become closer to the people with the change of the political order. It started from the fall of Soeharto in May 1998 and which was followed by the enactment of the decentralization policy in 2003. The decentralization policy offered opportunities and challenges as well as freedoms and restrictions because its regulations supported and impededwomen's movement. Democratization, human rights and gender issues which were formerly the concern of central government in Jakarta through the Ministry of Women Affairs, were administratively structured down to the regional and local levels starting in the year of 2000. However, these administrative innovations did not only offer prospects for increasing women's movementbut also were simultaneously challenged by other opposite currents. The resurgence of Islamic revivalism and ethnonationalism in which particular local values and religious understandings were misappliedfilled this new phenomenon. Indeed, the constructed kodratperempuan came to face new contestations especially because of the upsurge of Islamic revivalism that tends towards putting women back into the home. Women were given more opportunities such as more access to political roles, yet at the same time, they also had to deal with new challenges like those who belong to womenunfriendly Islamic groups. As this situation has already been a reality for almost two decades, studies on women's leadership deserve to receive a much broaderacademic response.

The perception of kodratperempuan (constructed female characteristics) embedded in social practices, is believed for years to hamper women's civic engagement. The study contrasts this view, arguing that kodrat does hinder women's participation but not entirely. In other words, the 
perception of kodrat supports women's participation limitedly. The scope of this limitation is flexible and can be changed over times and contexts depending on women's situation and capacities themselves. The more conducive the context they live in, and the more capabilities they have, the more likely women can engage socially. Therefore, it discusses women's strategies (experiences) in their effort to overcome the limitations.

Throughout Indonesia's history and especially during the New Order era, healthcare was consideredas ideal domains for women, and they were urged to become involved in healthcare programs. This trend continued after Soeharto'sfall. Therefore, it is interesting to discuss the dynamics of women's social engagement, particularly women's leadership in these areas in spite of the confinements being imposed on women through the construction of kodratperempuan, both in their private and public lives. The main point for the discussion of kodrat in the healthcare sector is the activities of women as Posyandu cadres. Integrated Village Health Service Post or in Bahasa Indonesia called PosPelayananTerpadu(Posyandu) is the Indonesian State's integrated health care program for mothers and children under five. The program is a continuation of the previous community health program, called Village Community Health Development Program (Pembangunan KesehatanMasyarakatDesa/PKMD) that the government formally introduced in 1977. The World Health Organization (WHO) and United Nations International Children's Emergency Fund (UNICEF) organized an International Conference on Primary Health Care (PHC) in Alma Ata in 1978 which produced the Alma Ata Declaration. The following year in 1979, the WHO introduced PHC [1]. These initiatives called on all governments in the world to formulate national PHC policies, programs, and strategies [2]. The main concern of this new strategy was community participation [3]. The strategy aimed to involve the community in health services by recruiting volunteers and training them on basic health matters and skills. People among the communities themselves were the targets of this recruitment of health workers because they were assumed to be closer to villagers than the State's health staff and because the people counted on them [3].

\section{METHOD}

In this study, I adopt a descriptive analytic approach [4]. I get the data from fieldwork which was conducted mainly in Tasikmalaya Regency and Tasikmalaya City and took 16 months between 2008 and 2010. Also, I did interviews to elicit information about external realities (e.g., facts, events) and internal experiences (e.g., feelings and meanings) [5]. Using Giddens's perspective of an agency, the study seeks for internal and external factors that influence agents' perspective and praxis [6]. By adopting Giddens's agency perspective, my interpretation of the data focused on illustrating the dynamics of women's leadership within the nuance of the perception of kodratperempuan, as a representation of Muslim women's efforts to signify their existence in society as citizens.

The term leadership is used not only as "an activity practiced by individuals" but also as "a process located in social activity". Leadership here is contextualized as a photeric, a model of leadership which positions it as a shared experience and as a social practice [7]. There is also the participative and democratic nuances [7] that provide space and opportunity for women's leadership in the mainstream tradition. The way this study discussesleadershipin two dimensions: leadership trajectory and leadership performance or experience.

Cultural citizenship is a term used to designate "the engaged citizen." It refers to an attribute of an individual, "a capacity to participate as an effective citizen," and "a set of cultural competencies that individuals had or did not have." [8]. The cultural competences may be in the sense of membership, belonging, rights or obligations. Women were, and over and over again continue to be, seen as neglected State citizens, and even considered as occupying the lowest citizenship rank throughout most of human history [9]. They are situated in this discriminative stand and try to engage socially, taking advantage of citizenship spheres. Like men, they practice citizenship as democratic citizens, citizens that are "capable of acting both autonomously and responsibly." [9] In this study, their social expressions of citizenship are restricted to their roles as health-volunteers.

\section{DISCUSSION}

Women's citizenship can be seen as an effort to include them fully in society as citizens. After being neglected in a long history of citizenship, women are now positioned better because of the contemporary democratization process. They are trying to gain an equal place as citizens through their social practices. One of the main issues is the matter of women's inclusion and exclusion as full citizens. In Indonesia, like in other countries, women's inclusion and exclusion as members of society was and is determined by both internal and external factors. The internal factors may refer to their 
knowledge, skills, networks, and the mentality of the women themselves. External factors may include 'the general nature of the practices and contexts' which were and are patriarchal. One common thing is the women's ability to engaging in and enacting social activities usually take place within their perceived kodrat. Within the basic elements of citizenship such as membership, belonging, and rights and obligations, women's cultural citizenship represents a continuous effort to shed the assumption that they are lower and second-class citizens, "incorporated into explicit consideration of family and as extensions of men's agency.” [9]. The nature of inclusion and exclusion may refer to a sense of belonging. In this assumption, women belong to the family, and this is kodrat that they perceive as normal. It constitutes their ideal role, space, and opportunity. Their role, space, and opportunity outside this construction are considered different. However, whether within the traditionally constructed kodrat or new influences, women have dynamics which are characterized as fluid and in continuous contestation and negotiation.

The history of women in Indonesia reflects the extension and limitation of their social roles and social engagement. In everyday life, as illustrated by Barbara Andaya and Ann Kumar, South-East Asian women had space and the opportunity to engage in both the private and public spheres [10]. The trend of restricting women's civic engagement started as a consequence of external influences such as those from the Western and Middle Eastern countries. As the time went by, this trend placed women mostly at home. Up to the present, women's civic engagement has navigated between restricting and liberating discourse resources while women now tend to have more room for a liberating resource discourse.

Based on the lessons learned in the Tasikmalaya context, the exclusion or inclusion of women's citizenship depends on the women themselves and on the settings that situate them. As their capacities increase over time, women's social engagement evolves more dynamic. They started by gaining support, usually from their spouses and families, and then they tried to improve their abilities and enhance their influence by pursuing an education at higher degrees, as some women did, or by resorting to the learning-by-doing strategy. At the same time, they received training, participated in cadre workshops and competitions as in the case of Posyandu. All this knowledge, experience, skills, participation and networking refined their traditional identities and constructed new ones. Within their traditional roles at home, women confidently accept other roles as long as they have their husbands' consent and their families' support. Spouses and family members usually support women's involvement in Islamic educational institution activities as long as the women themselves have the necessary knowledge, skills, and intention to do so. As years passed, their roles increased and extended to other areas of activities. This improvement could be in the number of classes where they teach, the level of the education they provide or in their teaching field, whereas the extension could be from teacher to preacher, or even from a social activist to a politician. Spouses also supported women's involvement in health program activities because they consider health and mother-child care are essential for the wellbeing of their own families. Posyandu cadres commonly added that the reason for their participation in the posts' activities was to learn and to make friends. Once they had committed themselves as cadres, they were exposed to new opportunities, spaces, and networking. They used their basic knowledge and skills in administration and the management of the health post. They were also introduced to new spaces and networks, such as at health posts (in their own houses or at independent posts), Pusat Kesehatan Masyarakat (Puskesmas or Community Health Post), village offices, ward administration, the city's or regency's health offices, and other offices like the military post at the city or regency level which have the same program on mother and child care. Occasionally, some of them were also introduced to offices at the provincial or even national level for annual competitions or to attend coordination meetings with other Posyandu volunteers. For example, Enok Tati Rohayati, transformed from housewife to the head of the cadres of PosyanduPuspa Indah in Tawang, Tasikmalaya City, and she became coordinator of Birth Control Information in the Tawang Sub-district. She developed her links not only within local health offices, the local village, Sub-district and city office administration but also in military offices to help them disseminate information and to accompany mothers and children to get health services. Many of her neighbors trusted her to assist them in getting health care. Though it was a voluntary program, she was happy because her efficiency was needed and in return, she also earned some money from the service she offered. She often participated in coordination meetings, competitions, and workshops on health and democracy issues [11].

Female Posyandu cadres' experiences confirm the assumption that although their cultural citizenship actualization functions within patriarchal precepts, in fact, it extends female's agency in society. They all confessed to having asked their husbands' permission and had considered the potential benefits to help them improve their health status. Their social engagement also reflected the 
extension of the male agency regarding how their involvement in social activities represented the family. One of them told me that mothers would not come with their children to the post if their husbands had not permitted them. To some extent, their cultural citizenship seemed operative within the sphere of their husbands' influence. However, these points do not negate the fact that being involved in voluntary activities which are in line with their constructed kodrat gave them the opportunities and the space to enable them to join and enact leadership at the same time. Here, inclusion and exclusion as parts of their full citizen membership reflect the women's continuous negotiation with their cultural identities.

\section{CONCLUSION}

The relation between woman's perception of kodratperempuan and her public health engagement provides familiar and comfortable space. She receives support from both internal agencies (e.g., husband) and the external one (e.g.,the government with PHC program). With this situation and help, a woman can extend her citizenship role from being only as a housewife (IbuRumahTangga/IRT) to an active and well-accepted citizen. This finding confirms Hunter's conclusion that female Posyandu cadres represent an expression of citizenship which entails women to be "good citizens" due to the State's discursive practice of placing them as supporting agents.However, Hunter's argument lies more on external factors, i.e., State ideology, Pancasila, PKK and the like. These external factors shape women's ideal roles for them. Although directed, cadres in her opinion are at the same time also restricted and not treated as equal agents. Also, these discursive practices of the external factors seem in her eyes undeniable. Therefore, for her, the appropriate way to describe Posyandu cadres' role is as "good citizens." However, this study suggests that she overlooks the implications of the existing restriction. This study finds that cadres have plenty of opportunity and space to engage in and, as experienced by the cadres I interviewed, that they can pass over existing boundaries.

The cadres I interviewed were mostly IRTs (housewives). It means that women are supporting agents, are second-class citizens and are not equal partners in line with their ideal role as prescribed by the constructed kodratperempuan. Nevertheless, after having been active in Posyandu activities for a while, cadres are poured with new knowledge, trained in basic health science, make new friends, are channeled to different organizations, and above all, they construct their leadership trajectory and legacy. Cadres are subject to change as they begin to extend their roles as soon as they improve their skills, knowledge, and networks.

All in all, being a Posyandu cadre can be seen as a way of expressing citizenship regarding rights and responsibilities, as well as belonging and participation. This expression is an impressive effort of women as citizens. Their activity as cadres is a representation of active female citizenship. Their effort so far could be considered as a significant effort in paving their way to equality.

\section{References}

[1] WHO, 1979. Primary Health Care, WHO, Geneva.

[2] Koesoebjono-Sarwono, Solita. 1993.Community Participation in Primary Health Care in an Indonesian Setting. Leiden: PhD Thesis University of Leiden, p. 6.

[3] Kölmann, Nathalie G.E.. 1992. The Management and Utilization of Posyandu in Central Java: A Case Study. Paper prepared the Workshop Health Care in Java, Past and Present, Leiden 7-8 May 1992. Leiden: KITLV.

[4] Robson, Colin. 1993 first Edition, 2002.Real World Research. Second Edition. Malden, Oxford, Victoria: Blackwell Publishing.

[5] Silverman, D. and Marvasti, A. 2008. Doing Qualitative Research: A Comprehensive Guide. Thousand Oaks, CA: Sage.

[6] Giddens, Anthony. 1993. New Rules of Sociological Methods. Stanford: Stanford University Press.

[7] Stead, Valerie and Elliott, Carole. 2009. Women's Leadership. Hampshire: Palgrave Macmillan.

[8] Gattinger, Caroline Andrew Monica (eds.), 2005. Accounting for Culture: the Thinking through Cultural Citizenship. Ottawa: The University of Ottawa Press.

[9] Stevenson, Nick. 2003. Cultural Citizenship: Cosmopolitan Questions. Berkshire: Open University Press.

[10] Kumar, Ann.2008. PrajuritPerempuanJawa: KesaksianIhwalIstana danPolitikJawaAkhir Abad e18. Jakarta: KomunitasBambu.

[11] Interview with Enok Tati Rohayati: August 1, 2010 